\title{
Optimum experimental design of a monitoring network for parameter identification at riverbank well fields
}

\author{
Ping Wang a,b,c,*, Sergey P. Pozdniakov ${ }^{\mathrm{b}}$, Vsevolod M. Shestakov ${ }^{\mathrm{b}}$ \\ ${ }^{a}$ Key Laboratory of Water Cycle E Related Land Surface Processes, Institute of Geographic Sciences and Natural Resources Research, Chinese Academy of Sciences, \\ 11A, Datun Road, Chaoyang District, Beijing 100101, PR China \\ ${ }^{\mathrm{b}}$ Department of Hydrogeology, Moscow State University, GSP-1, Leninskie Gory, Moscow 119899, Russia \\ ${ }^{\mathrm{c}}$ Department of Hydrology and Water Resources, University of Arizona, 1133 E James E Rogers Way, Tucson, AZ 85721, USA
}

\section{A R T I C L E I N F O}

\section{Article history:}

Received 1 November 2014

Received in revised form 31 January 2015

Accepted 2 February 2015

Available online 10 February 2015

This manuscript was handled by Peter K.

Kitanidis, Editor-in-Chief, with the

assistance of Xunhong Chen, Associate

Editor

\section{Keywords:}

Groundwater and surface water interactions

Riverbank filtration

Riverbed clogging

Hydraulic conductivity

MODFLOW

\begin{abstract}
S U M M A R Y
A steady-state flow regime in riverbank well fields is often violated by fluctuations in river stages and variations in groundwater extraction. In this study, a criterion of quasi-steady flow during filtration processes at riverbank well fields was introduced. Under the assumption of steady-state flow, an analytical approach for determining the key hydraulic parameters (aquifer transmissivity and riverbed filtration resistance) between a stream and a hydraulically connected aquifer during riverbank filtration was presented. An optimal regular observation network (consisting of the locations of monitoring wells and the observation regime), which is based on the model-oriented approach using an example of a riverbank well field near the Kuybyshev Reservoir, Russia, was designed to minimise the uncertainty in the estimates of hydraulic parameters. The analyses showed that the initial recession in the surface water levels for the simplest constant groundwater withdrawal patterns can be used to determine the key hydraulic parameters; the error in these estimated parameters was less than $7 \%$ or $12 \%$, depending on the designed monitoring network. When comparing the two typical monitoring networks, observation line A-A that passes midway through the water supply wells performed better than observation line B-B that passes through the water supply wells when estimating the hydraulic parameters. The results of this study can be used as a reference for designing and optimising a monitoring network that aims to determine the key hydraulic parameters at riverbank well fields.
\end{abstract}

(ㄷ) 2015 Elsevier B.V. All rights reserved.

\section{Introduction}

Riverbank filtration (RBF) is a managed surface-groundwater interaction process in which surface water is forced to flow downward through porous media into production wells that are installed on the banks of rivers and lakes under pumping stress (Dillon et al., 2002; Grischek and Ray, 2009; Ray et al., 2002). $\mathrm{RBF}$, which is an important part of managed aquifer recharge (MAR) systems (Rauch-Williams et al., 2010), has been used for water supplies in Europe along the Rhine, Elbe, Danube, and Seine Rivers for over a century (Schubert, 2002; Tufenkji et al., 2002) and it has provided the majority of the drinking water for large cities in Russia (Filimonova and Shtengelov, 2013), the USA (Hoppe-Jones

\footnotetext{
* Corresponding author at: Key Laboratory of Water Cycle \& Related Land Surface Processes, Institute of Geographic Sciences and Natural Resources Research, Chinese Academy of Sciences, 11A, Datun Road, Chaoyang District, Beijing 100101, PR China.

E-mail address: wangping@igsnrr.ac.cn (P. Wang).
}

et al., 2010; Roy et al., 2012), China (Wu et al., 2007) and other countries (Hamdan et al., 2013; Lee et al., 2009; Polomčić et al., 2013; Shamsuddin et al., 2014) over the last few decades. The obvious advantage of RBF is the conjunctive use of infiltrated surface water and groundwater from the alluvial catchments of intake structures (Polomčić et al., 2013), which ensure long-term productivity and stability of the water supply (Sprenger et al., 2011). Additionally, surface water contaminants can be significantly removed or degraded as the infiltrating water moves from the river/lake to the production wells due to a combination of physicochemical and microbiological processes (Hiscock and Grischek, 2002; Maeng et al., 2010; Singh et al., 2010; Weiss et al., 2005).

However, as noted by Doussan et al. (1998) and Schubert (2002), poor surface water quality, heavy clogging of the riverbed, and accidental pollution have already greatly threatened RBF systems. Importantly, the sustainability of RBF is affected by particulate organic matter, which intensifies physical or chemical clogging of riverbed (Baveye et al., 1998; Henzler et al., 2014; 
Hiscock and Grischek, 2002; Yong et al., 2013) and significantly reduces the hydraulic conductivity of riverbed as well as well yield (Schubert, 2002). Moreover, the hydraulic relationship between surface water and aquifers may be transited from connected to disconnected systems (Brunner et al., 2011) due to the increasing hydraulic resistance of riverbed sediments during RBF processes (Wiese and Nützmann, 2009). Thus, sustainable water management at riverbank well fields requires fundamental investigations into the hydraulic properties of riverbed, which are considered an important indicator of riverbed clogging processes.

Numerous approaches have been developed to investigate the hydraulic properties of riverbed, including grain-size distribution analysis (Alyamani and Sen, 1993), in-stream methods (Cardenas and Zlotnik, 2003; Chen, 2000; Landon et al., 2001; Rosenberry, 2008), environmental tracer experiments (Anderson, 2005; Constantz, 2008; Roshan et al., 2012; Vogt et al., 2012), a vadose zone monitoring system (Dahan et al., 2007, 2009), water balance techniques (Fleckenstein et al., 2010; Kalbus et al., 2006; Shanafield and Cook, 2014), and integrated surface-groundwater numerical modelling (Boano et al., 2013; Brunner et al., 2010; Doppler et al., 2007; Lautz and Siegel, 2006). The hydraulic properties of the riverbed, which are estimated using the aforementioned methods, are mostly assumed to be constant over time in studies on riverbank filtration processes and the related surface-groundwater interactions (Baveye et al., 1998). However, field investigations have documented both spatial and temporal variability in the hydraulic properties of riverbed (Chen et al., 2010; Genereux et al., 2008; Leek et al., 2009), particularly in riverbank well fields, which are mainly associated with dynamic hydrological processes, such as groundwater extraction and changes in surface water levels (Levy et al., 2011; Zlotnik and Huang, 1999). Therefore, as indicated by Schubert (2002), the hydraulic properties of riverbed are principal factors for determining the volume of the bank filtrate, which cannot be regarded as constant during RBF investigations.

To understand the dynamic behaviour of the hydraulic properties of riverbed sediments during RBF processes, monitoring concepts that include continuous measurements of the surfacegroundwater level and well productivity over long periods (Shestakov, 1993) must account for the dynamic hydrological processes of the entire riverbank system (Hiscock and Grischek, 2002; Schubert, 2002). The ultimate configuration of the monitoring network aims to determine the key hydraulic characteristics of the groundwater flow systems (Heath, 1976; Hudak and Loaiciga, 1993; Zhou et al., 2013), which are based on the parameter estimations using monitoring materials (Loaiciga, 1989). Nevertheless, the interpretation of the monitoring data, which targets the understanding of surface-groundwater interactions under induced filtration (e.g., riverbed clogging processes), remains a challenge due to the non-steady-state flow conditions under RBF. A reliable estimation of hydraulic parameters is highly dependent on the design of the monitoring network (Alzraiee et al., 2013), which includes two important components: the network density and the sampling frequency (Zhou, 1996). Conversely, such interpretation should also serve as a guide for optimising the existing monitoring network for further changes in hydrological and other conditions after a long period of RBF (Hudak and Loaiciga, 1993; Shestakov, 1993). In this study, we provide an analysis of the hydrological conditions that formed during RBF at the riverbank well fields near the Kuybyshev Reservoir, Russia. The primary objectives of this study are to (i) reveal the filtration processes under the non-steady flow regime induced by surface water level fluctuations and by the instability of water withdrawal at the riverbank well fields; (ii) present methods for interpreting monitoring data at riverbank well fields using a steady-state assumption; and (iii) provide a numerical, model-based design of a monitoring network that aims to identify hydraulic parameters under induced filtration.

\section{Theoretical foundation: analytical solution for parameter estimations under quasi-steady flow}

Under steady-state flow conditions, the hydraulic properties of an aquifer and a semipervious riverbed are two key parameters that determine the surface-groundwater interaction at the riverbank well fields. The hydraulic properties of a semipervious riverbed that partially penetrates a horizontal non-leaky water table aquifer can be determined by the coefficient of the vertical leakage through the semipervious riverbed, $\chi_{0}$ (Shestakov, 1995):

$\chi_{0}=\frac{k_{0}}{m_{0}}$,

where $k_{0}$ and $m_{0}$ are the hydraulic conductivity [L/T] and thickness [L], respectively, of the semipervious layer of the riverbed. To quantify the water exchange between the surface water and groundwater at riverbank well fields, Hantush (1965) and Shestakov (1965) proposed the concept of hydraulic resistance, which is defined as the equivalent loss through a horizontal semipervious layer of an insignificant storage capacity located between the aquifer and the river.

Consider the typical conditions of a two-layer structure of groundwater flow for an aquifer underlying a semipervious layer beneath a river with width $N$ (Fig. 1). The aquifer below the riverbed, which has a transmissivity $T_{0}$, is covered with a semipervious layer that has a thickness $m_{0}$ and a vertical hydraulic conductivity $k_{0}$. The effective length of additional hydraulic resistance in aquifer $\Delta L$, which has the same hydraulic resistance as the riverbed, can be calculated by the following equation (Pozdniakov and Shestakov, 1998; Shestakov, 1965):

$\Delta L=\frac{T}{\sqrt{T_{0} \chi_{0}}} \operatorname{coth}\left(N \sqrt{\frac{\chi_{0}}{T_{0}}}\right)$,

where $T$ is the transmissivity of the main aquifer at the riverbank $\left[\mathrm{L}^{2} / \mathrm{T}\right]$. By introducing the effective length $\Delta L$, which refers to the general hydraulic resistance of the riverbed, the riverbank is virtually shifted this distance and the river is changed from a semipervious-bottom river to a river that is perfectly connected with the aquifer (Fig. 1); this newly shifted river is used with the steady-state analytical boundary conditions with a constant head at the riverbank.

$T_{0}=T$ is usually assumed when calculating $\Delta L$ with Eq. (2). If a river has an infinite width, for example, an artificial reservoir or a large river where $N>3 \Delta L$, then a simplified relationship between $\chi_{0}$ and $\Delta L$ would be produced (Pozdniakov and Shestakov, 1998; Shestakov, 1965):

$\chi_{0}=T /(\Delta L)^{2}$.

We assume that the flow in the main aquifer is essentially horizontal; therefore, the flow in the top semipervious layer is essentially vertical. As an approximation, we ignore the storage in the upper semipervious layer. The simplest and most common method of determining the parameter $\Delta L$ is to use the analytical solution that is widely used for steady (quasi-steady) flow regimes within single-layer aquifer systems. Systematic measurements of the river-water stages and the groundwater levels from the observation wells provide essential data needed to evaluate the interaction between groundwater and surface water. The observation line consists of six OWs, which are located in the direction of the groundwater flow and are installed in the aquifer with heads of $\mathrm{H}_{1}, \mathrm{H}_{2}, \mathrm{H}_{3}, \mathrm{H}_{4}, \mathrm{H}_{5}$, and $\mathrm{H}_{6}$ (Fig. 1 ). Note that the nearest $\mathrm{OW}$ to the riverbank is no closer to the shoreline than the equivalent thickness of the aquifer (Shestakov, 1995).

Observations of the steady-state flow regime from the two wells along the observation line (OW1 and OW2) in the aquifer 


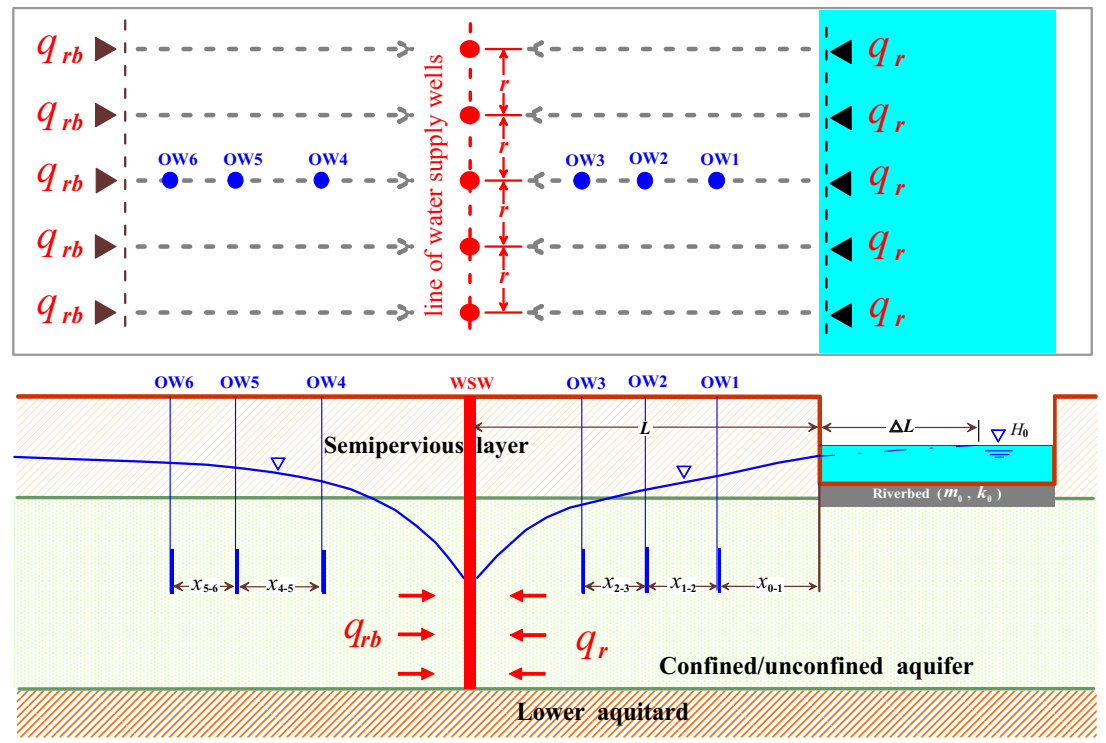

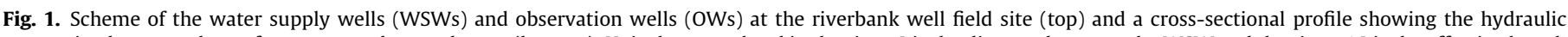

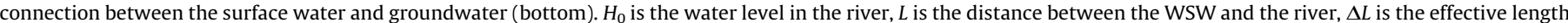

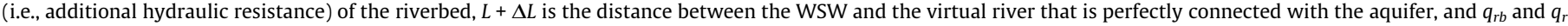
are the flow rates per unit width from the riverbank and river, respectively.

(Fig. 1) allow for the determination of $\Delta L$ without considering the influence of infiltration or evaporation (Shestakov, 1965):

$\Delta L=\left(H_{0}-H_{1}\right) / I_{1-2}-x_{0-1}$,

where $H_{0}$ is the water level in the river, $I_{1-2}$ is the hydraulic gradient in the direction of the flow between OW1 and OW2, and $x_{0-1}$ is the distance from OW1 to the riverbank.

According to the groundwater balance analysis, the parameter $T$ can be determined from the groundwater regime observations (Fig. 1):

$T=q_{w} /\left(I_{r}+I_{r b}\right), \quad I_{r}=I_{1-2}=\frac{H_{1}-H_{2}}{x_{1-2}}, \quad I_{r b}=I_{4-5}=\frac{H_{5}-H_{4}}{x_{4-5}}$,

where $q_{w}$ is the flow rate per unit width that follows the lines of $\mathrm{OW} ; I_{r}$ and $I_{r b}$ are the hydraulic gradients directed away from the river and riverbank, respectively; $x_{1-2}$ is the distance between OW1 and OW2; and $x_{4-5}$ is the distance between OW4 and OW5. When pumping groundwater at the riverbank well fields (Fig. 1), the OW closest to the water supply well (WSW) lines should be avoided by locating the zone where the equipotential lines bend towards the pumping wells.

$q_{w}$ in Eq. (4) is calculated as the ratio of the pumping rate $Q_{w}$ to the average distance between the WSWs $r$. When different pumping rates have the value of $Q_{w}^{0}$ along the line of the $O W, Q_{w}^{-}$and $Q_{w}^{+}$ are to the left and right, respectively, of the OW line; then, $Q_{w}=\left(Q_{w}^{-}+2 Q_{w}^{0}+Q_{w}^{+}\right) / 4$ and $r=\left(r^{-}+r^{+}\right) / 2 . r^{-}$and $r^{+}$are the distances between the wells to the left and right, respectively, of the OW line (Fig. 2a). When the OW lies between two WSWs that are at distances of $r^{-}$and $r^{+}$(i.e., between the wells to the left and right of the OW line) and when the flow rates of the WSW are indicated by $Q_{w}^{-}$and $Q_{w}^{+}$, respectively (Fig. 2b), then $Q_{w}=\left(Q_{w}^{-}+Q_{w}^{+}\right) / 2$ and $r=r^{-}+r^{+}$.

Note that when using the above analytical solutions, the premise of steady (quasi-steady) flows should be diagnosed by applying the criterion of stability to the head difference ratio of the two pairs of OWs (Shestakov and Wang, 2004):

$\Delta \bar{H}=\left(H_{1}-H_{2}\right) /\left(H_{2}-H_{3}\right) \approx$ const.

The steady-state flow assumptions should be examined alongside the river and alongside the riverbank (watershed); during floods, infiltration often intensifies due to melting snow cover and rainfall in spring and summer. In these conditions, the steady-state flow regime on the riverbank side is invalid (Shestakov and Pozdniakov, 2003).

\section{Study area}

The Kuybyshev Reservoir (Fig. 3), which was formed by damming the flow of the middle Volga River via the Volga Hydroelectric
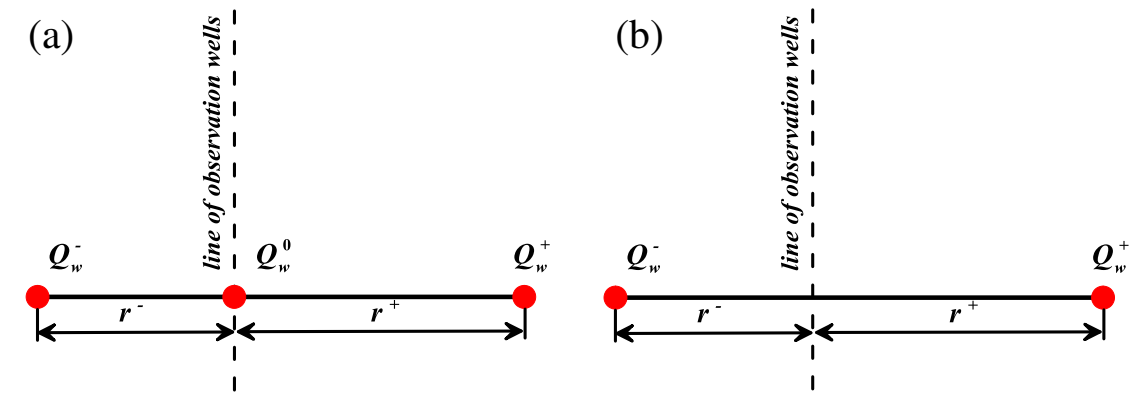

Fig. 2. Layout of the water supply wells and the line of observation wells. 


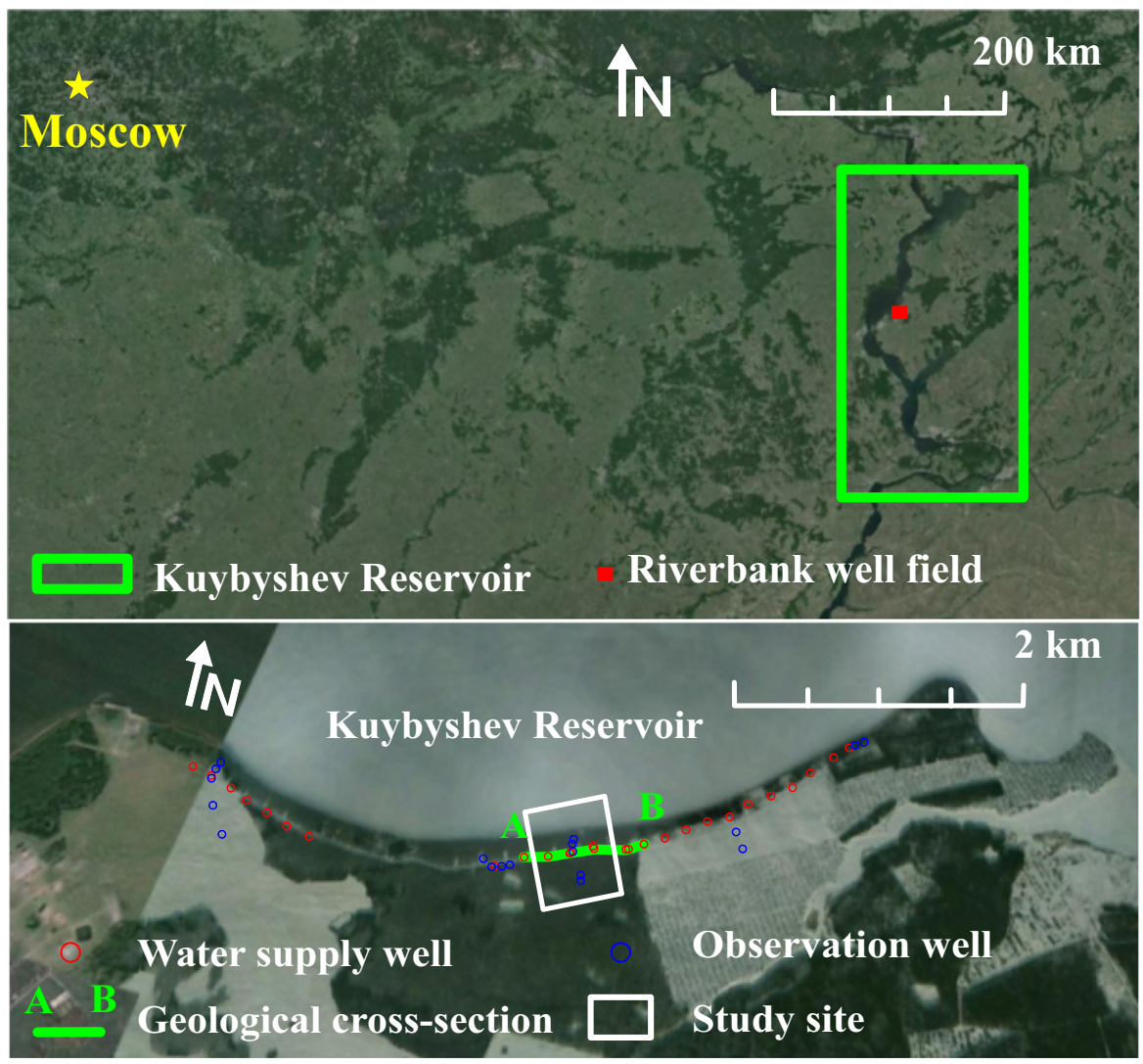

Fig. 3. The location of the Kuybyshev Reservoir (top) and the studied riverbank well field along the reservoir (bottom).

Power Station, is the largest reservoir in Europe, with a surface area of $6450 \mathrm{~km}^{2}$ (Rainey, 1999). The average width of the Kuybyshev Reservoir within the study region is approximately $11 \mathrm{~km}$, and the average depth is $9 \mathrm{~m}$. The water level in the reservoir from October 2004 to October 2005 varied between $50.67 \mathrm{~m}$ and $53.47 \mathrm{~m}$; the water level is lowest in spring and highest in summer (Fig. 4). The water level in the reservoir was $50.90 \mathrm{~m}$ during this period, with a $95 \%$ exceedance probability.

The riverbank well field in this study is represented as a linear line with 28 WSWs, which are located parallel to the shore of the Kuybyshev Reservoir; the wells are 150-250 m from the shoreline (Fig. 3). The distance between the water supply wells is approximately $200 \mathrm{~m}$, except four pairs of water supply wells that

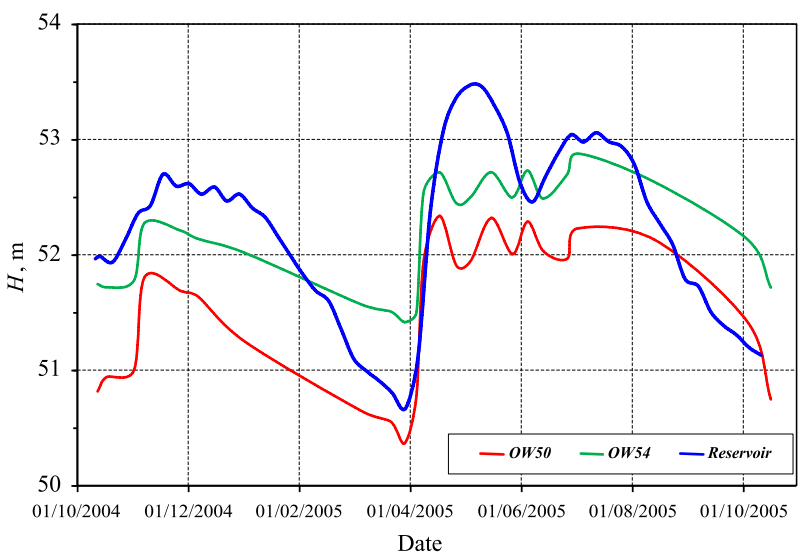

Fig. 4. The fluctuations of the water levels $(H, \mathrm{~m})$ in the observation wells (OW 50 and OW 54) and in the Kuybyshev Reservoir from October 2004 to October 2005. are only 8-10 m apart. The wells have a diameter of 254-305 mm (10-12 in.), and they are drilled to a depth of 60-96 m.

Aquifers in the study site typically consist of unconsolidated sediments from Middle Quaternary (Fig. 5). The main aquifer for groundwater withdrawal is composed of Likhvin-Dnieper sediments $\left(a Q_{I I} l+d\right)$, including sand with gravel and pebbles over a 50-60 $\mathrm{m}$ thickness. Low-aquitard aquifers contain Jurassic clays to a depth of $80 \mathrm{~m}$. The layer of brown silt at a 20-30 m depth separates the upper Odintsovo-Moscow aquifer $\left(\mathrm{aQ}_{\mathrm{II}} \mathrm{Od}+\mathrm{ms}\right)$ from the lower Likhvin-Dnieper aquifer $\left(\mathrm{aQ}_{\mathrm{II}} \mathrm{l}+\mathrm{d}\right)$, acting as a regional confining layer for the lower aquifer (Fig. 5). The static groundwater level is found at an absolute altitude of $49-53 \mathrm{~m}$. The average hydraulic conductivity is $38 \mathrm{~m} / \mathrm{d}$, and the specific yield is estimated as 0.15 .

A set of 18 observation wells was installed at the riverbank well field sites to collect data on the groundwater level. For a detailed analysis of the surface water and groundwater interactions at typical riverbank well field sites, a polygon that encompasses a comprehensive groundwater monitoring network was selected (Fig. 3). As shown in Fig. 6, the water intake is represented as a linear series of 6 WSWs (Nos. 15, 16, 17, 18a, 46, and 48) that are located along the coast of the reservoir at a distance of 200$250 \mathrm{~m}$ from the shoreline. The distance between the WSWs is 180-220 m, with the exception well Nos. 17 and 46, which are $14 \mathrm{~m}$ apart. The pumping rates of the WSWs in this area are as follows: $\quad Q_{15}=4320 \mathrm{~m}^{3} / \mathrm{d}, \quad Q_{16}=1440 \mathrm{~m}^{3} / \mathrm{d}, \quad Q_{17}=2095 \mathrm{~m}^{3} / \mathrm{d}$, $Q_{18 a}=1730 \mathrm{~m}^{3} / \mathrm{d}, Q_{46}=2990 \mathrm{~m}^{3} / \mathrm{d}$, and $Q_{48}=4320 \mathrm{~m}^{3} / \mathrm{d}$.

In this area, the groundwater monitoring network is composed of observation well Nos. 50-54 (Fig. 6). The distance from the shoreline to OW No. 50 is $95.8 \mathrm{~m}$, and the distances between the observation wells are as follows: $x_{50-51}=47.4 \mathrm{~m}, x_{51-52}=62.5 \mathrm{~m}$, $x_{52-53}=212.5 \mathrm{~m}$, and $x_{53-54}=48.0 \mathrm{~m}$. An example of the groundwater level dynamics for OW Nos. 50 and 54 during 2004-2005 is 


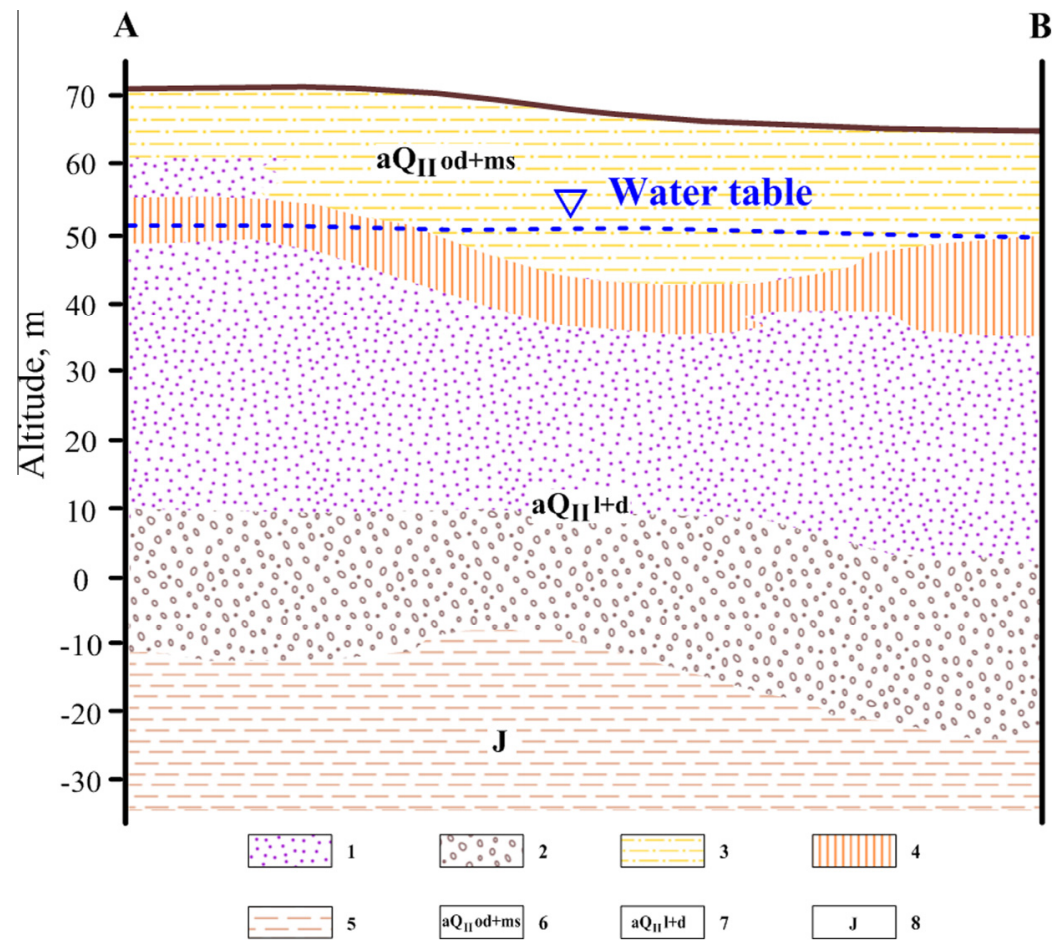

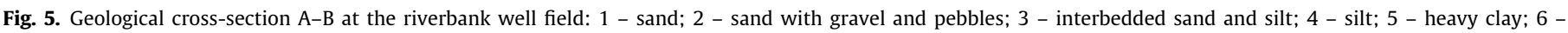
Odintsovo-Moscow deposits $\left(\mathrm{aQ}_{\mathrm{II}} \mathrm{Od}+\mathrm{ms}\right) ; 7$ - Likhvin-Dnieper deposits $\left(\mathrm{aQ}_{\mathrm{II}} \mathrm{l}+\mathrm{d}\right)$; and 8 - Jurassic deposits. Section A-B is shown in Fig. 3.

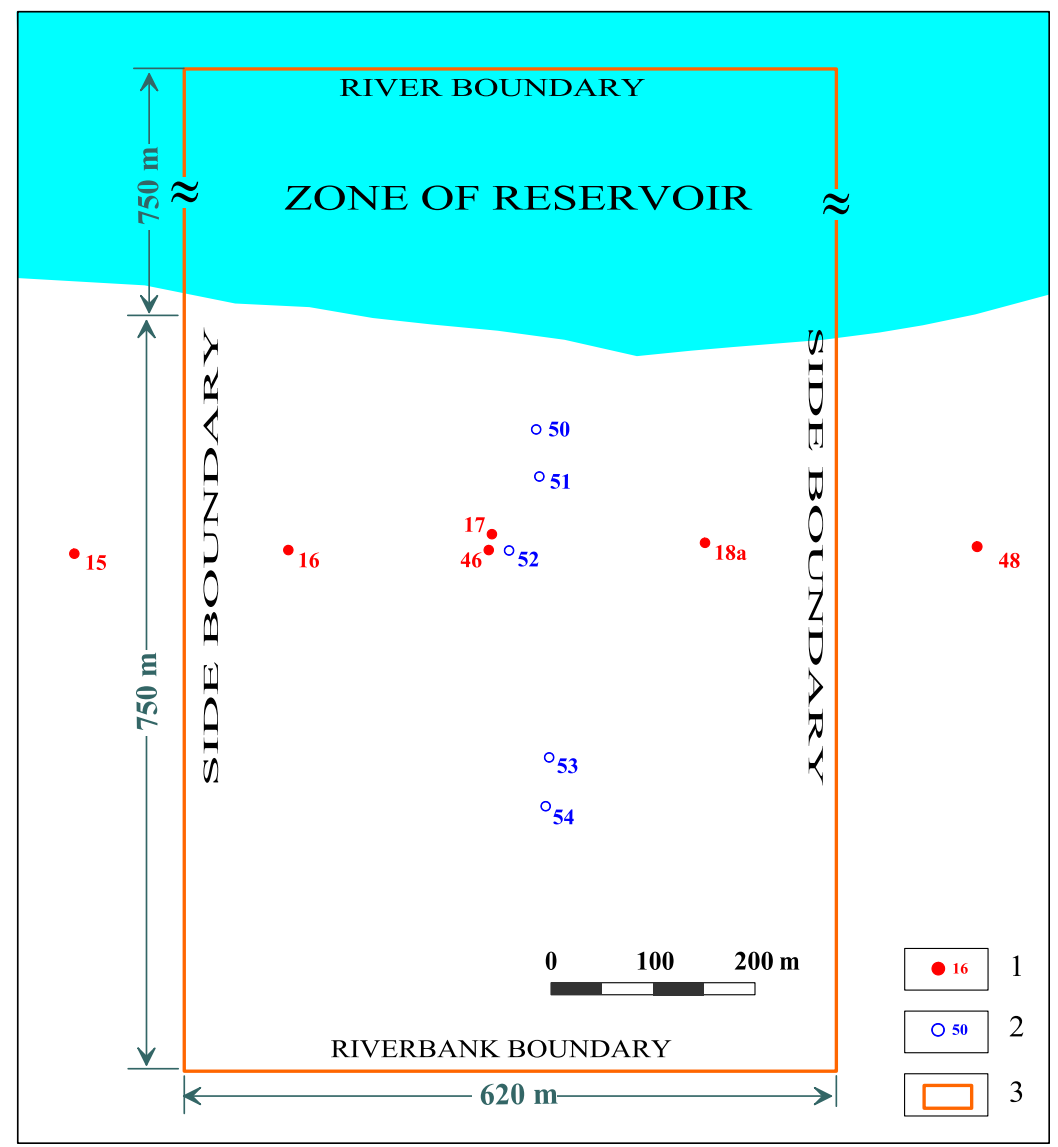

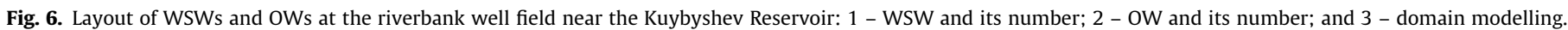


shown in Fig. 4, which demonstrates a large fluctuation over time. The unsteady groundwater flow regime in this area is primarily conditioned by fluctuations in the reservoir stage. In addition, the unstable dynamics of groundwater withdrawal at the riverbank well field substantially enhance the unsteady flow regime.

\section{Model-oriented experimental design of the monitoring network}

\subsection{Model setup}

A mathematical modelling framework was applied to determine the structure of the groundwater flow and the hydraulic head in the observation wells by simulating the groundwater flow system at the riverbank well site. The designed model domain covered WSW Nos. 16, 17, 18a and 46, and no-flow boundaries were used for the side lines between WSW Nos. 15-16 and Nos. 18a and 48 (Fig. 6). The model domain is $1500 \mathrm{~m} \times 620 \mathrm{~m}$. To simplify the simulations, the average width of the reservoir $\left(N_{r}\right)$ was set to $750 \mathrm{~m}$ (Fig. 6), which is $50 \%$ of the model domain. The aquifer has impermeable boundaries defined by flow lines. The grid cells of the model are $10 \mathrm{~m} \times 10 \mathrm{~m}$ in size. A total of 9300 active cells were used to discretise the model domain.

Similar to the approach used by Filimonova and Shtengelov (2013), a leaky riverbank aquifer system that consists of the confined/unconfined aquifer and the overlying less permeable layer was adopted in this study. The lower aquifer was set as confined/ unconfined because the groundwater pumping from this aquifer may possibly lower the water table; as a result, part of the initial confined aquifer, particularly in the vicinity of WSWs, may become unconfined (Wang et al., 2009). Assuming the drawdown induced by groundwater abstraction is small compared with the saturated thickness, a specified-thickness approximation (Pinder and Bredehoeft, 1968; Sheets et al., 2015) was applied in this study; therefore, the transmissivity of the lower aquifer was considered constant throughout the simulation. The relationship between the lower confined/unconfined aquifer and the upper low permeability layer was determined by the coefficient of vertical leakage. Based on the analysis of hydro-geological conditions at the study site (Wang, 2008) and the typical storativity for alluvial sands (Shestakov, 2002), the following values of hydraulic parameters were used for the model experiments: the transmissivity of the lower aquifer $T=2000 \mathrm{~m}^{2} / \mathrm{d}$, the storage coefficient of the lower aquifer $S=1.0 \cdot 10^{-3}$, the specific yield of the lower aquifer $S_{y}=0.15$, and the coefficient of vertical leakage through the upper layer $\chi=0.21 / \mathrm{d}$.

At the northern boundary, a head-dependent flux boundary was introduced below the reservoir. The field of the reservoir was specified by the area of flow under the reservoir with a transmissivity $T$ and a leakage coefficient of the clogging layer $\chi_{0}$, which is associated with the resistance parameter of the reservoir bed $\Delta L$. According to the results received by interpreting the data of the regime observations at a typical alluvial riverbank (Shestakov and Wang, 2004), the following aquifer properties were assigned to the representative hydrogeological conditions: $T=2000 \mathrm{~m}^{2} / \mathrm{d}$ and $\Delta L=250 \mathrm{~m}$. As shown in Section 2, a simplified relationship between $\chi_{0}$ and $\Delta L$ may be determined by Eq. (2a) when the width of the reservoir $N$ is three times larger than $\Delta L$; therefore, the equivalent coefficient of the vertical leakage through the semipervious riverbed for the reservoir is $\chi_{0}=0.0321 / \mathrm{d}$.

The analysis of the regime observations at OW 53 and OW 54 for 2004-2005 revealed that the average hydraulic gradient from the riverbank to the reservoir was $3.20 \times 10^{-3}$. Thus, the groundwater flow recharge from the riverbank to the modelled boundary $q_{r b}$ is equal to $6.40 \mathrm{~m}^{2} / \mathrm{d}$ per unit width.
Note that among the factors that result in an unsteady flow regime at the riverbank well field, the most undesirable factor is the disordered dynamics of groundwater withdrawal, i.e., random changes in the temporal pumping patterns, which cause large changes in the groundwater flow structure. Nevertheless, the influence of groundwater withdrawal on water flow patterns can be eliminated during monitoring. Thus, a constant groundwater withdrawal rate, $Q=2750 \mathrm{~m}^{3} / \mathrm{d}$ for each WSW, was assumed during the model experiments to analyse the groundwater flow patterns.

The stream-aquifer system was modelled using PMWIN (Chiang, 2005) as the pre- and post-processor for MODFLOW (Harbaugh et al., 2000). Using the River package in MODFLOW for simulating head-dependent flux boundaries (Harbaugh et al., 2000), the leakage coefficient $\chi_{0}$ was determined through the hydraulic conductance of the stream-aquifer interconnection $C_{\text {riv }}$ which represents the resistance to the flow between the surface water and the groundwater caused by the riverbed, i.e., $C_{r i v}=F \chi_{0}$, where $F$ is the surface area of a model cell (Harbaugh et al., 2000).

The flow boundary condition at the riverbank (southern) boundary of the model domain was defined as a specified-flux boundary, which was represented by a constant flow rate per unit width from the riverbank $q_{r b}$. Groundwater flow recharge $q_{r b}$ at the riverbank boundary was determined by setting additional infiltration $w^{*}$ in the boundary cells, which equals the ratio of the total inflows from the riverbank to the area of the modelled riverbank boundary, i.e., $w^{*}=\left(q_{r b} \times L_{r b}\right) /\left(L_{r b} \times N_{r b}\right)$, where $L_{r b}$ is the length of the modelled riverbank boundary, and $N_{r b}$ is the width of the grid cell at the modelled riverbank boundary.

\subsection{Model-oriented optimisation for designing monitoring networks}

To design a monitoring network, the most important components to define are (1) the network density (the number of observation wells and their locations) and (2) the sampling frequency (the number of observations or samples per unit time) (Zhou, 1996). In this section, a different observation network for the groundwater system was designed to optimise the monitoring network in the riverbank well fields using stream-aquifer interaction models. Effective estimation of hydraulic parameters $\Delta L$ and $T$ under the different designs of groundwater monitoring generally drives the optimisation criteria.

Two parts of the optimisation of the monitoring network design are considered. The first part is the optimisation of the monitoring network configuration under steady flow conditions. The steady-state method may produce more reliable experimental data than the unsteady-state method because it is based on the direct application of the generalised Darcy's law. The second part is the optimisation of the observation regime under non-steady conditions to select a period that represents quasi-steady-state flow.

\subsubsection{Experimental configuration design of the monitoring network}

For the steady-state flow simulation, the lower aquifer was modelled under confined/unconfined conditions as represented by a single layer with a constant thickness of $52.5 \mathrm{~m}$ while neglecting the vertical leakage from the upper semipervious layer. We considered a uniform distribution of groundwater withdrawals at the riverbank well field, in which $Q_{16}=Q_{46}=Q_{18 a}=2750 \mathrm{~m}^{3} / \mathrm{d}$, and the water level in the reservoir was steady at $50.90 \mathrm{~m}$ (a $95 \%$ exceedance probability during the study period). The initial hydraulic heads over the model domain were assumed to be equivalent to the average static groundwater level, which was approximately $51 \mathrm{~m}$.

Two typically designed groundwater observation lines were selected for the model experiments (Fig. 7): the A-A line that passes midway between the WSWs and the B-B line that passes through the WSWs. For each designed observation line, three 


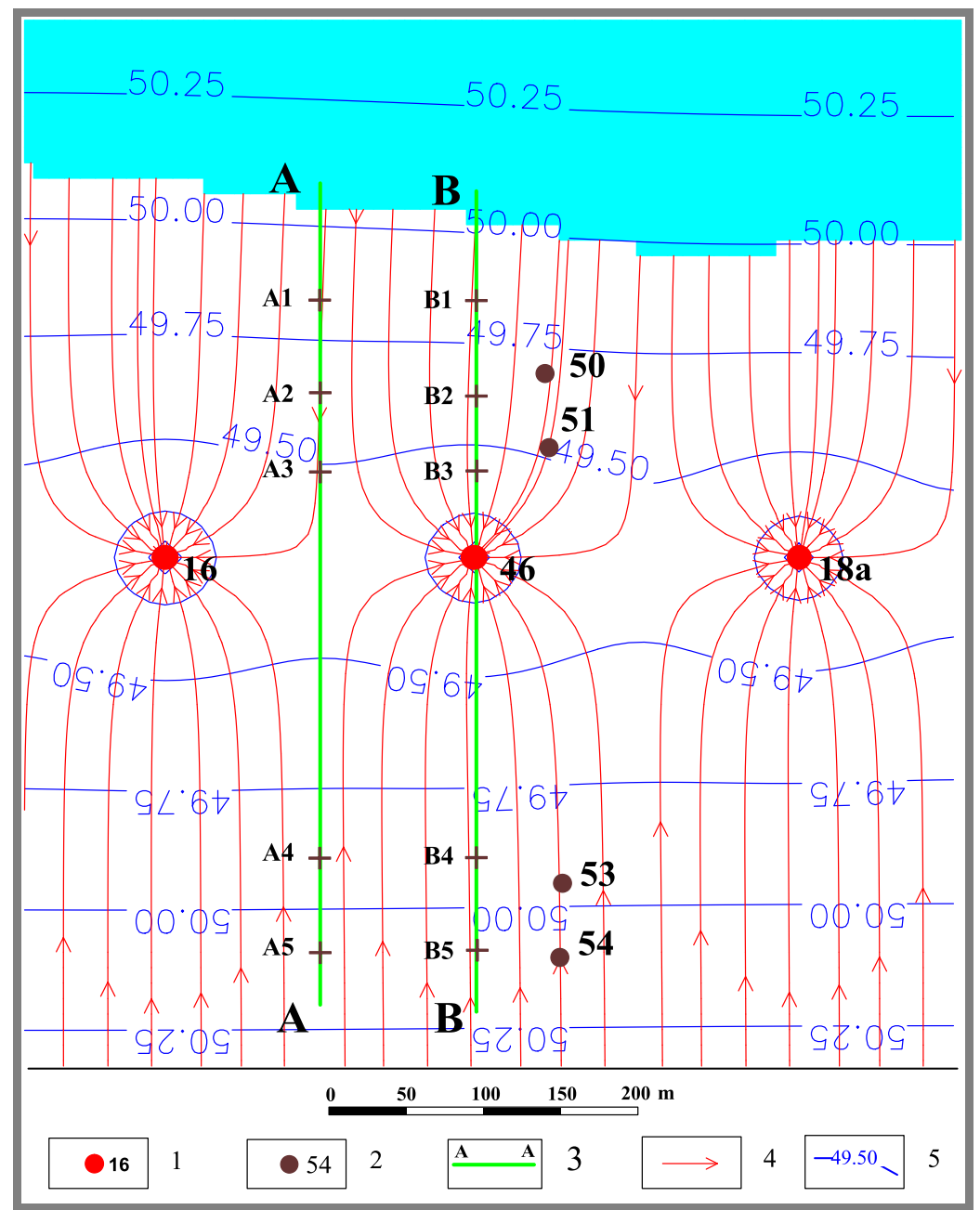

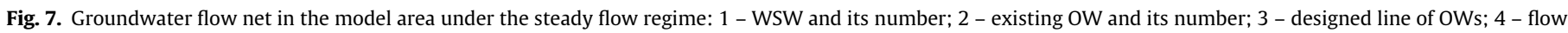
line; and 5 - equipotential line.

OWs were located on the side of the reservoir and two OWs were located on the side of the riverbank. As noted by Shestakov and Wang (2004), a vertical flow can be observed in the vicinity of the WSW and river shoreline; therefore, the locations of the OWs should be far from these zones, and the distance between the nearest OW and the shoreline and between the nearest OW and the WSW should be larger than the aquifer thickness. Under the aforementioned conditions, both designed observation lines consist of 5 OWs, whose distances (Fig. 1) along the A-A line are $x_{0-1}=60 \mathrm{~m}$, $x_{1-2}=60 \mathrm{~m}, x_{2-3}=50 \mathrm{~m}$, and $x_{4-5}=60 \mathrm{~m}$ and whose distances along the $\mathrm{B}-\mathrm{B}$ line are $x_{0-1}=50 \mathrm{~m}, x_{1-2}=60 \mathrm{~m}, x_{2-3}=50 \mathrm{~m}$, and $x_{4-5}=60 \mathrm{~m}$.
Fig. 7 shows a symmetrical groundwater flow structure by simulating steady-state groundwater flow. For the existing and designed observation lines, hydraulic parameters $T$ and $\Delta L$, based on the simulated hydraulic head in the observation wells, were estimated using the analytical calculations of Eqs. (3) and (4). Note that the OW closest to a WSW along the designed observation lines $\mathrm{A}-\mathrm{A}$ and $\mathrm{B}-\mathrm{B}$ (OW A3 and OW B3) is likely located in the zone that is clearly influenced by groundwater withdrawal from the nearby WSW. Therefore, the modelled hydraulic head in OW A3 and OW B3 were not used to estimate hydraulic parameters $T$ and $\Delta L$. The estimated $T$ and $\Delta L$ using the analytical calculation for the three observation lines are presented in Table 1.

Table 1

The parameters $T$ and $\Delta L$ under a steady-flow regime using analytical calculations.

\begin{tabular}{|c|c|c|c|c|c|c|}
\hline Observation line & Design of the OW & $I_{r b}(-)$ & $I_{r}(-)$ & $T\left(\mathrm{~m}^{2} / \mathrm{d}\right)$ & $\Delta L(\mathrm{~m})$ & $\chi_{0}(1 / \mathrm{d})$ \\
\hline \multicolumn{7}{|c|}{ Scenario 1: uniform distribution of groundwater withdrawal $\left(Q_{16}=Q_{18 a}=Q_{46}=2750 \mathrm{~m}^{3} / \mathrm{d}\right)$} \\
\hline Existing line & OW $50,51,53,54$ & $3.2 \times 10^{-3}$ & $3.4 \times 10^{-3}$ & 2010 & 260 & 0.030 \\
\hline A-A & OW A1, A2, A4, A5 & $3.2 \times 10^{-3}$ & $3.3 \times 10^{-3}$ & 2030 & 260 & 0.030 \\
\hline $\mathrm{B}-\mathrm{B}$ & OW B1, B2, B4, B5 & $3.2 \times 10^{-3}$ & $3.6 \times 10^{-3}$ & 1950 & 240 & 0.034 \\
\hline \multicolumn{7}{|c|}{ Scenario 2: non-uniform distribution of groundwater withdrawal $\left(Q_{16}=1440 \mathrm{~m}^{3} / \mathrm{d}, Q_{17}=2095 \mathrm{~m}^{3} / \mathrm{d}, Q_{18 a}=1730 \mathrm{~m}^{3} / \mathrm{d}, Q_{46}=2990 \mathrm{~m}^{3} / \mathrm{d}\right)$} \\
\hline Existing line & OW $50,51,53,54$ & $3.4 \times 10^{-3}$ & $4.6 \times 10^{-3}$ & 1860 & 190 & 0.052 \\
\hline A-A & OW A1, A2, A4, A5 & $3.3 \times 10^{-3}$ & $3.6 \times 10^{-3}$ & 2090 & 250 & 0.033 \\
\hline B-B & OW B1, B2, B4, B5 & $3.5 \times 10^{-3}$ & $4.6 \times 10^{-3}$ & 2000 & 190 & 0.055 \\
\hline
\end{tabular}


As shown in Table 1, the hydraulic gradient from the riverbank $\left(I_{r b}\right)$, which is defined by measurements in two OWs that are far from the WSWs, is stable. A slight difference in the hydraulic gradients is directed away from the reservoir $\left(I_{r}\right)$; the estimated hydraulic gradient increases from observation line A-A $\left(3.3 \times 10^{-3}\right)$ to $\mathrm{B}-\mathrm{B}\left(3.6 \times 10^{-3}\right)$. Compared with the set values $\left(T=2000 \mathrm{~m}^{2} / \mathrm{d}\right.$ and $\left.\Delta L=250 \mathrm{~m}\right)$, the parameters $T$ and $\Delta L$ can be estimated with an error of less than $5 \%$ for all three observation lines, including the existing line (Table 1 ).

In practice, groundwater withdrawals from WSWs in the riverbank well fields are often non-uniform. A model experiment with the actual groundwater withdrawals from the WSW in the study site $\left(Q_{16}=1440 \mathrm{~m}^{3} / \mathrm{d}, \quad Q_{17}=2095 \mathrm{~m}^{3} / \mathrm{d}, \quad Q_{18 a}=1730 \mathrm{~m}^{3} / \mathrm{d}\right.$, and $\left.Q_{46}=2990 \mathrm{~m}^{3} / \mathrm{d}\right)$ was conducted. All of the other boundary conditions remained the same as those in the aforementioned model experiment. Under these conditions, the modelled flow structure slightly deviates from the symmetrical conditions, depending on the degree of the unevenness of the groundwater withdrawals from the WSW. As shown in Table 1, the estimated hydraulic gradient directed away from the riverbank $\left(I_{r b}\right)$ is similar for the three observation lines. However, the estimated hydraulic gradient directed away from the reservoir $\left(I_{r}\right)$ greatly varied between the observation lines, from $3.6 \times 10^{-3}$ to $4.6 \times 10^{-3}$. The estimated parameters $T$ and $\Delta L$ conformed to the set values based only on observation line $\mathrm{A}-\mathrm{A}$, and the parameter $\Delta L$ was underestimated by nearly $25 \%$ for the existing line and the observation line B-B.

Note that the total groundwater withdrawals remained the same in both scenarios (uniform and non-uniform distributions of groundwater withdrawals from the WSWs), whereas the estimated hydraulic gradients from the riverbank and reservoir only remained similar for observation line $\mathrm{A}-\mathrm{A}$. Therefore, the designed observation line A-A better follows the local groundwater flow structure and provides more reliable information for estimating hydraulic parameters at the riverbank well fields. During groundwater monitoring, maintaining a relatively uniform distribution of groundwater withdrawals from WSWs is important for estimating the hydraulic parameters at riverbank well fields.

\subsubsection{Experimental design for the observation regime}

In practice, the assumption of a steady-state flow regime is typically violated because of fluctuations in the reservoir stage and because of unstable water withdrawals; thus, changes occur in the water withdrawals from a different WSW and the riverbank well fields (i.e., switching WSWs) are unstable. The latter condition creates remarkable difficulty in interpreting the data of regime observations. As a result, the groundwater flow structure can change substantially; therefore, when monitoring groundwater to estimate hydraulic parameters, abrupt changes in the groundwater withdrawal at riverbank well fields should be avoided. In this section, we considered the simplest unsteady flow at the riverbank well fields caused by changes in the reservoir stage and assumed that the groundwater pumping patterns remained unchanged. As described in Section 4.1, a simplified leaky riverbank aquifer system, in which a less permeable layer is located above the main aquifer, was used to simulate the subsurface flow processes.

For the unsteady flow regime, we consider a scenario in which a uniform distribution of groundwater withdrawals occurs, as described in Section 4.2.1. As shown in Fig. 4, the river stage in the reservoir varies greatly throughout the period from October 2004 to October 2005, changing from $50.67 \mathrm{~m}$ to $53.47 \mathrm{~m}$. The simulated groundwater level under steady-state conditions at the first time step was used to define the initial hydraulic heads over the flow domain; for reference, the river stage was $51.97 \mathrm{~m}$. In accordance with the 54 measurements of the reservoir stage, the groundwater levels at the observation wells along both designed lines (A-A and B-B) were recorded using numerical modelling. Based on the simulated groundwater levels, a diagnostic assessment of the flow regime was conducted according to Eq. (5). The estimated $\Delta \bar{H}$ varied from 1.33 to 1.41 using the recorded water levels along observation line A-A and changed from 0.93 to 1.13 based on the recorded water levels along observation line $B-B$. The difference in the estimated $\Delta \bar{H}$ for observation lines $\mathrm{A}-\mathrm{A}$ and $B-B$ is likely related to the different hydraulic heads in the well closest to the WSW between A-A and B-B. Obviously, the hydraulic head in OW B3 is more greatly affected by groundwater withdrawals from the WSW than OW A3. In this study, the estimated $\Delta \bar{H}$ based on the groundwater level records along observation line B-B (Fig. 8) was used to analyse the flow regime.

Fig. 8 shows that the changes in $\Delta \bar{H}$ and the fluctuations in $H_{0}$ have similar shapes; however, when the smooth decline lasted for a long period (e.g., January 2005-April 2005 and August 2005-October 2005), the value of $\Delta \bar{H}$ gradually decreased, depending on the recession of $H_{0}$, to a particular time and then stabilised. Based on the analysis of the temporal dynamics in $\Delta \bar{H}$ and $H_{0}$, the reservoir stage can be divided into periods of rise (I), sustained

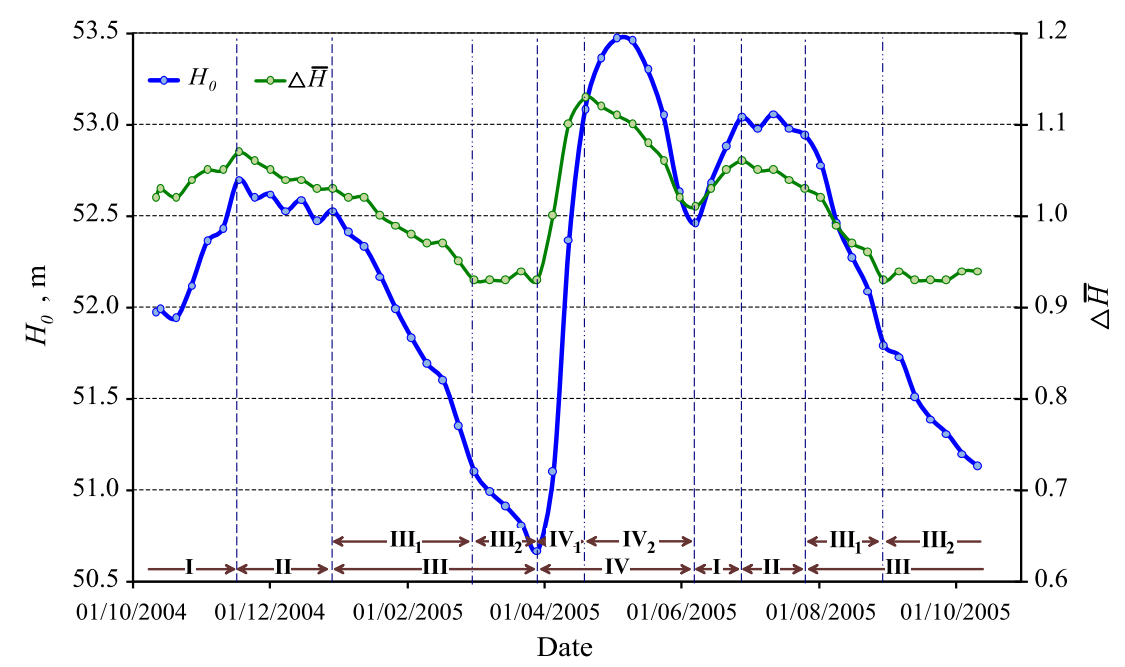

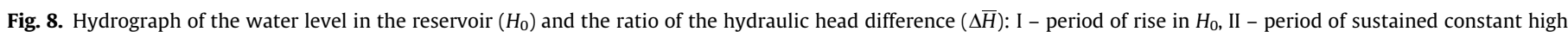

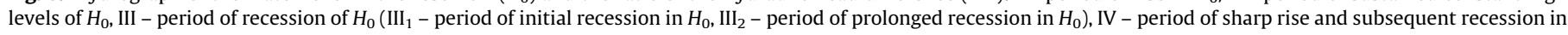
$H_{0}\left(\mathrm{IV}_{1}\right.$ - period of sharp rise in $H_{0}$, and $\mathrm{IV}_{2}$ - period of subsequent recession in $H_{0}$ ). 
constant high level (II), recession (III) and sharp rise followed by recession (IV); during a recession, periods of initial recession $\left(\mathrm{III}_{1}\right)$ and prolonged recession ( $\mathrm{III}_{2}$ ) occur (Fig. 8).

Temporal variations in $\Delta \bar{H}$ indicated an unsteady flow regime at the riverbank well fields due to river stage fluctuations, particularly in period IV when large changes in $\Delta \bar{H}$ (up to 0.20 ) occurred. In this study, we assumed that variations in $\Delta \bar{H}$ that are less than $10 \%$ of the average $\Delta \bar{H}$ in periods I-III are quasi-steady flow. The hydraulic parameters for the select periods using the analytical solutions (Eqs. (3) and (4)) for the steady-state flow regime were estimated for observation lines A-A (OWs A1, A2, A4, and A5) and $\mathrm{B}-\mathrm{B}$ (OWs B1, B2, B4, and B5). The results of the calculations are presented in Table 2.

According to the analytical solution based on the simulated groundwater levels, the estimated $T$ varied from $1970 \mathrm{~m}^{2} / \mathrm{d}$ to $2240 \mathrm{~m}^{2} / \mathrm{d}$ based on observation line A-A, which is approximately $4 \%$ larger than that based on observation line B-B (which varied from $1890 \mathrm{~m}^{2} / \mathrm{d}$ to $2150 \mathrm{~m}^{2} / \mathrm{d}$ ). The estimated parameter $\Delta L$ based on observation line A-A changed from $230 \mathrm{~m}$ to $300 \mathrm{~m}$, which is $20 \mathrm{~m}$ larger than that estimated by observation line B-B (which varied from $210 \mathrm{~m}$ to $280 \mathrm{~m}$ ).

The average estimated $\Delta \bar{H}$ for each regime period of I-III remained nearly the same between winter and summer-autumn, even though the average value of $H_{0}$ in each regime period in winter was lower than that in summer-autumn by approximately 20$30 \mathrm{~cm}$ (Fig. 8). The estimated hydraulic parameters were largely related to $\Delta \bar{H}$. As shown in Fig. 9, T exhibited a significantly negative linear relationship with $\Delta \bar{H}\left(R^{2}=0.87\right)$; however, a highly positive linear relationship between $\Delta L$ and $\Delta \bar{H}$ was identified $\left(R^{2}=0.85\right)$. Note that the estimated hydraulic parameters greatly

Table 2

Estimated hydraulic parameters $T$ and $\Delta L$ for different regime periods.

\begin{tabular}{|c|c|c|c|c|c|c|}
\hline \multirow{2}{*}{$\begin{array}{l}\text { Regime } \\
\text { period }\end{array}$} & \multicolumn{3}{|c|}{ Observation line $\mathrm{A}-\mathrm{A}$} & \multicolumn{3}{|c|}{ Observation line B-B } \\
\hline & $T\left(\mathrm{~m}^{2} / \mathrm{d}\right)$ & $\Delta L(\mathrm{~m})$ & $\chi_{0}(1 / d)$ & $T\left(\mathrm{~m}^{2} / \mathrm{d}\right)$ & $\Delta L(\mathrm{~m})$ & $\chi_{0}(1 / d)$ \\
\hline \multicolumn{7}{|c|}{ Winter (from October 2004 to April 2005) } \\
\hline I & 1980 & 300 & 0.022 & 1910 & 280 & 0.024 \\
\hline II & 1970 & 290 & 0.023 & 1890 & 270 & 0.026 \\
\hline $\mathrm{III}_{1}$ & 2130 & 250 & 0.034 & 2040 & 230 & 0.039 \\
\hline $\mathrm{III}_{2}$ & 2240 & 230 & 0.042 & 2150 & 210 & 0.049 \\
\hline \multicolumn{7}{|c|}{ Summer-autumn (from July 2005 to October 2005) } \\
\hline I & 2000 & 290 & 0.024 & 1930 & 270 & 0.026 \\
\hline II & 1970 & 290 & 0.023 & 1900 & 270 & 0.026 \\
\hline $\mathrm{III}_{1}$ & 2130 & 240 & 0.037 & 2050 & 220 & 0.042 \\
\hline $\mathrm{III}_{2}$ & 2230 & 230 & 0.042 & 2150 & 210 & 0.049 \\
\hline
\end{tabular}

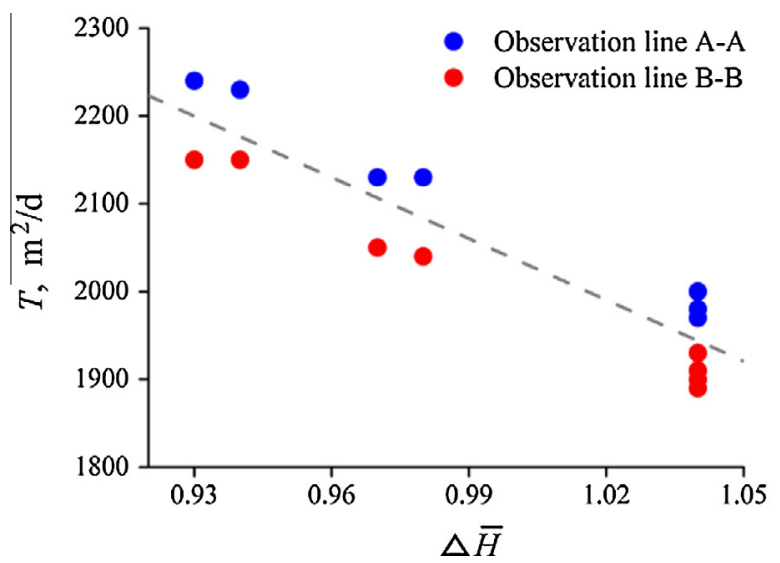

depended on the design of the observation line (including the location of the OW) and the fluctuations in river stage.

Comparing the set values of the hydraulic parameters $\left(T=2000 \mathrm{~m}^{2} / \mathrm{d}\right.$ and $\left.\Delta L=250 \mathrm{~m}\right)$, the hydraulic parameters quantified from observation line A-A were overall better than those based on observation line B-B. Specifically, observation line A-A resulted in a $7 \% T$ error and a $4 \% \Delta L$ error during the initial recession of $H_{0}\left(\mathrm{III}_{1}\right)$. Based on the aforementioned analysis, the estimated hydraulic parameters $T$ and $\Delta L$ were more favourable when they were calculated during the period of initial recession in $H_{0}$ along observation line $\mathrm{A}-\mathrm{A}$.

\section{Summary and discussion}

Estimations of the key properties of a groundwater flow system, such as the aquifer transmissivity $T$ and the effective length (i.e., additional hydraulic resistance) of the riverbed $\Delta L$, and their temporal effects on surface-groundwater interactions under forced filtration rely on a surface and groundwater monitoring network. An analysis of groundwater dynamics at the riverbank well fields near the Kuybyshev Reservoir showed that the steady-state flow regime is often violated due to the variations in groundwater extraction and fluctuations in river stages. A typical hydrograph for the reservoir during the study period can be used to distinguish the periods of rise (I), sustained constant high levels (II), recession (III) and sharp rise then subsequent recession (IV) in the pattern of the river water-level fluctuations; the period of recession can also be divided into periods of initial recession $\left(\mathrm{III}_{1}\right)$ and prolonged recession $\left(\mathrm{III}_{2}\right)$.

To estimate the two critical parameters that determine the surface-groundwater interactions under forced filtration and steady state flow assumptions, a diagnostic indicator of quasi-steady flow was introduced. Under the condition of permanent groundwater withdrawal patterns, the results of the groundwater flow simulations indicated that the changes in $\Delta \bar{H}$ accounted for less than $10 \%$ of the average $\Delta \bar{H}$ during periods I-III. Using the finite-difference equation, the estimation of hydraulic parameters $T$ and $\Delta L$, based on the simulated groundwater regime of the monitoring wells, demonstrated that the periods of initial recession in $H_{0}$ $\left(\mathrm{III}_{1}\right)$ are the most favourable for executing the regime observations; specifically, the errors in the estimated parameters were less than $7 \%$ when using observation line $\mathrm{A}-\mathrm{A}$ and $12 \%$ when using observation line B-B.

Based on the model experiments, the observation line that passes midway between the water-supply wells (the line A-A) slightly differed from the line that passes through the centre of the watersupply wells (line B-B) when determining the hydraulic para-

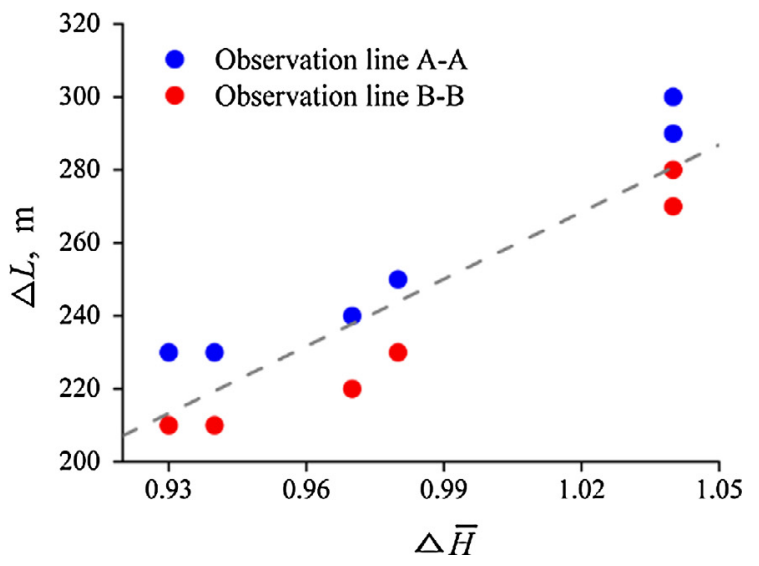

Fig. 9. The relationship between the ratio of the hydraulic head difference $\Delta \bar{H}$ and the hydraulic parameters $T$ (left) and $\Delta L$ (right). 
meters $T$ and $\Delta L$ under a uniform groundwater-withdrawal distribution at the riverbank well fields. However, under a non-uniform groundwater-withdrawal distribution at the WSW, the hydraulic parameters $T$ and $\Delta L$ were well estimated based on the simulated hydraulic head along observation line A-A. Notably, the assumption of essentially horizontal flow should not be applied in zones that are close to the water supply wells and the reservoir shoreline, where the vertical flow component is non-negligible. Therefore, when designing the observation line, special attention should be paid to the distance from the observation wells to the water supply wells and to the reservoir shoreline. Additionally, the observation wells should not be located in a zone with significant vertical flow (approximately the thickness of the aquifer) alongside the reservoir or alongside the water supply wells (Shestakov, 1995; Shestakov and Wang, 2004).

The hydraulic parameter $\Delta L$ was calculated without accounting for the impact of the storage capacity of the overlying semipervious layer on the changes in the groundwater levels. However, as shown by Wang (2008), quantifying the parameter $\Delta L$ to account for the overlying layer capacity under an unsteady flow regime did not significantly improve the $\Delta L$ estimation; however, it required significant development of the observation network. The main limitation of this work is that the analysis conducted to evaluate unsteady flow without considering the influence of groundwater withdrawal can be greatly modified both temporally and spatially during riverbank filtration. Therefore, further research should focus on a more comprehensive analysis of the unsteady flow induced by the combination of river-stage fluctuations and the instability of groundwater extraction to design a reliable groundwater network at riverbank well fields.

Lastly, the approach for estimating the hydraulic parameters based on the surface-groundwater monitoring network is the simplest case; however, the subsurface flow-generating mechanism in the riverbank well fields is more complex than assumed in this study. The riverbank filtration processes are complicated by developing local hydraulically transitional or disconnected zones (Brunner et al., 2009) within initially fully connected stream-aquifer systems, in which unsaturated zones develop under streambeds due to intensive pumping from the WSWs (Filimonova and Shtengelov, 2013; Rivière et al., 2014). In addition, thermal effects are known to cause significant changes in the hydraulic conductivity because the flow's kinematic viscosity is temperature dependent (Anderson, 2005; Nutting, 1930). Fluctuations in the diurnal/ seasonal surface water temperature may exert an important influence on the rates of induced infiltration from the river/reservoir to the subsurface due to the temperature-sensitive streambed hydraulic conductivity (Constantz et al., 1994; Jaynes, 1990; Kalbus et al., 2007). For the typical seasonal changes in the surface water temperature, i.e., $20^{\circ} \mathrm{C}$ (summer) to $5^{\circ} \mathrm{C}$ (winter), in the study area, the kinematic viscosity of the water changes by approximately $150 \%$. Assuming that the riverbed temperature change as the same magnitude as the surface water temperature change and neglecting the variations in the groundwater temperature, the hydraulic parameter of riverbed $\Delta L$ may experience an increase from summer to winter equal to the square root of the ratio of the kinematic viscosity of the water in cold and warm season (Eq. (2a)), i.e., by approximately $120 \%$. Therefore, traditional approaches for estimating hydraulic parameters based on the field monitoring of hydrological conditions in stream-aquifer systems require systematic observations of the potential development of unsaturated zones beneath the streambed and the thermal regime of surface/subsurface flow. Moreover, as indicated by Brunner et al. (2012) and Schilling et al. (2014), traditional observations of hydraulic heads or river stages are insufficient in inverse problem solutions for estimating hydraulic parameters. Accordingly, a fully coupled, physically based 3-D numerical model that solves for flow and heat transport through saturated-unsaturated porous media (Anderson, 2005) should be implemented for reducing the uncertainty in parameter estimations (Brunner et al., 2012) using the combined pressure and temperature measurements of the surface water-streambed-aquifer system.

\section{Acknowledgements}

This research was partially supported by grants from the National Natural Science Foundation of China (No. 41301025), the Russian Federation Basic Research Foundation (No. 13-0591161-ГФЕН_a), the NSFC-RFBR Program 2013-2014 (Nos. 41311120068 and 13-05-91161), and the Visiting Professorship for Senior International Scientists, Chinese Academy of Sciences (No. 2012T1Z0037). The authors would like to thank Dr. A.A. Kuvaev and Dr. D.B. Goncharenko for the materials and valuable discussions. The authors gratefully acknowledge the Editor, Peter K. Kitanidis, the anonymous associate editor, and three anonymous reviewers for their valuable comments and suggestions that led to substantial improvements in the manuscript. The first author would also like to thank the China Scholarship Council (No. 201304910063) for supporting this research.

\section{References}

Alyamani, M.S., Sen, Z., 1993. Determination of hydraulic conductivity from complete grain-size distribution curves. Ground Water 31 (4), 551-555.

Alzraiee, A.H., Bau, D.A., Garcia, L.A., 2013. Multiobjective design of aquifer monitoring networks for optimal spatial prediction and geostatistical parameter estimation. Water Resour. Res. 49 (6), 3670-3684.

Anderson, M.P., 2005. Heat as a ground water tracer. Ground Water 43 (6), 951-968.

Baveye, P., Vandevivere, P., Hoyle, B.L., DeLeo, P.C., de Lozada, D.S., 1998 Environmental impact and mechanisms of the biological clogging of saturated soils and aquifer materials. Crit. Rev. Environ. Sci. Technol. 28 (2), 123-191.

Boano, F., Revelli, R., Ridolfi, L., 2013. Modeling hyporheic exchange with unsteady stream discharge and bedform dynamics. Water Resour. Res. 49 (7), 4089-4099.

Brunner, P., Cook, P.G., Simmons, C.T., 2009. Hydrogeologic controls on disconnection between surface water and groundwater. Water Resour. Res. 45 (1), W01422.

Brunner, P., Simmons, C.T., Cook, P.G., Therrien, R., 2010. Modeling surface watergroundwater interaction with MODFLOW: some considerations. Ground Water 48 (2), 174-180.

Brunner, P., Cook, P.G., Simmons, C.T., 2011. Disconnected surface water and groundwater: from theory to practice. Ground Water 49 (4), 460-467.

Brunner, P., Doherty, J., Simmons, C.T., 2012. Uncertainty assessment and implications for data acquisition in support of integrated hydrologic models. Water Resour. Res. 48 (7), W07513.

Cardenas, M.B., Zlotnik, V.A., 2003. A simple constant-head injection test for streambed hydraulic conductivity estimation. Ground Water 41 (6), 867-871.

Chen, X., 2000. Measurement of streambed hydraulic conductivity and its anisotropy. Environ. Geol. 39 (12), 1317-1324.

Chen, X., Song, J., Wang, W., 2010. Spatial variability of specific yield and vertical hydraulic conductivity in a highly permeable alluvial aquifer. J. Hydrol. 388 (34), 379-388.

Chiang, W.-H., 2005. 3D-Groundwater Modeling with PMWIN: A Simulation System for Modeling Groundwater Flow and Transport Processes, second ed. Springer, pp. 397.

Constantz, J., 2008. Heat as a tracer to determine streambed water exchanges. Water Resour. Res. 44, W00D10.

Constantz, J., Thomas, C.L., Zellweger, G., 1994. Influence of diurnal variations in stream temperature on streamflow loss and groundwater recharge. Water Resour. Res. 30 (12), 3253-3264.

Dahan, O., Shani, Y., Enzel, Y., Yechieli, Y., Yakirevich, A., 2007. Direct measurements of floodwater infiltration into shallow alluvial aquifers. J. Hydrol. 344 (3-4) $157-170$

Dahan, O. et al., 2009. In situ monitoring of water percolation and solute transport using a vadose zone monitoring system. Vadose Zone J. 8 (4), 916-925.

Dillon, P.J., Miller, M., Fallowfield, H., Hutson, J., 2002. The potential of riverbank filtration for drinking water supplies in relation to microsystin removal in brackish aquifers. J. Hydrol. 266 (3-4), 209-221.

Doppler, T., Franssen, H.-J.H., Kaiser, H.-P., Kuhlman, U., Stauffer, F., 2007. Field evidence of a dynamic leakage coefficient for modelling river-aquifer interactions. J. Hydrol. 347 (1-2), 177-187.

Doussan, C., Ledoux, E., Detay, M., 1998. River-groundwater exchanges, bank filtration, and groundwater quality: ammonium behavior. J. Environ. Qual. 27 (6), 1418-1427. 
Filimonova, E., Shtengelov, R., 2013. The dependence of stream depletion by seasonal pumping on various hydraulic characteristics and engineering factors. Hydrogeol. J. 21 (8), 1821-1832.

Fleckenstein, J.H., Krause, S., Hannah, D.M., Boano, F., 2010. Groundwater-surface water interactions: new methods and models to improve understanding of processes and dynamics. Adv. Water Resour. 33 (11), 1291-1295.

Genereux, D.P., Leahy, S., Mitasova, H., Kennedy, C.D., Corbett, D.R., 2008. Spatial and temporal variability of streambed hydraulic conductivity in West Bear Creek, North Carolina, USA. J. Hydrol. 358 (3-4), 332-353.

Grischek, T., Ray, C., 2009. Bank filtration as managed surface-groundwater interaction. Int. J. Water 5 (2), 125-139.

Hamdan, A. Sensoy, M., Mansour, M., 2013. Evaluating the effectiveness of bank infiltration process in new Aswan City, Egypt. Arab. J. Geosci. 6 (11), 4155-4165.

Hantush, M.S., 1965. Wells near streams with semipervious beds. J. Geophys. Res. 70 (12), 2829-2838.

Harbaugh, A.W., Banta, E.R., Hill, M.C., McDonald, M.G., 2000. MODFLOW-2000, the US Geological Survey Modular Ground-water Model: User Guide to Modularization Concepts and the Ground-water Flow Process, Open File Rep. 00-92. USGS, Denver, CO.

Heath, R.C., 1976. Design of ground-water level observation-well programs. Ground Water 14 (2), 71-77.

Henzler, A.F., Greskowiak, J., Massmann, G., 2014. Modeling the fate of organic micropollutants during river bank filtration (Berlin, Germany). J. Contam. Hydrol. 156, 78-92.

Hiscock, K.M., Grischek, T., 2002. Attenuation of groundwater pollution by bank filtration. J. Hydrol. 266 (3-4), 139-144.

Hoppe-Jones, C., Oldham, G., Drewes, J.E., 2010. Attenuation of total organic carbon and unregulated trace organic chemicals in U.S. riverbank filtration systems. Water Res. 44 (15), 4643-4659.

Hudak, P.F., Loaiciga, H.A., 1993. An optimization method for monitoring network design in multilayered groundwater flow systems. Water Resour. Res. 29 (8), $2835-2845$.

Jaynes, D.B., 1990. Temperature variations effect on field-measured infiltration. Soil Sci. Soc. Am. J. 54 (2), 305-312.

Kalbus, E., Reinstorf, F., Schirmer, M., 2006. Measuring methods for groundwatersurface water interactions: a review. Hydrol. Earth Syst. Sci. 10 (6), 873-887.

Kalbus, E. et al., 2007. New methodology to investigate potential contaminant mass fluxes at the stream-aquifer interface by combining integral pumping tests and streambed temperatures. Environ. Pollut. 148 (3), 808-816.

Landon, M.K., Rus, D.L., Harvey, F.E., 2001. Comparison of instream methods for measuring hydraulic conductivity in sandy streambeds. Ground Water 39 (6), $870-885$.

Lautz, L.K., Siegel, D.I., 2006. Modeling surface and ground water mixing in the hyporheic zone using MODFLOW and MT3D. Adv. Water Resour. 29 (11), 1618 1633.

Lee, J.-H. et al., 2009. Characterizing riverbank-filtered water and river water qualities at a site in the lower Nakdong River basin, Republic of Korea. J. Hydrol. 376 (1-2), 209-220.

Leek, R. et al., 2009. Heterogeneous characteristics of streambed saturated hydraulic conductivity of the Touchet River, south eastern Washington, USA. Hydrol. Process. 23 (8), 1236-1246.

Levy, J. et al., 2011. The impact of storm events on a riverbed system and its hydraulic conductivity at a site of induced infiltration. J. Environ. Manage. 92 (8), 1960-1971.

Loaiciga, H.A., 1989. An optimization approach for groundwater quality monitoring network design. Water Resour. Res. 25 (8), 1771-1782.

Maeng, S.K., Ameda, E., Sharma, S.K., Grützmacher, G., Amy, G.L., 2010. Organic micropollutant removal from wastewater effluent-impacted drinking wate sources during bank filtration and artificial recharge. Water Res. 44 (14), $4003-$ 4014.

Nutting, P.G. 1930. Physical analysis of oil sands. AAPG Bull. 14 (10), 1337-1349.

Pinder, G.F., Bredehoeft, J.D., 1968. Application of the digital computer for aquifer evaluation. Water Resour. Res. 4 (5), 1069-1093.

Polomčić, D., Hajdin, B., Stevanović, Z., Bajić, D., Hajdin, K., 2013. Groundwater management by riverbank filtration and an infiltration channel: the case of Obrenovac, Serbia. Hydrogeol. J. 21 (7), 1519-1530.

Pozdniakov, S.P., Shestakov, V.M., 1998. Analysis of groundwater discharge with a lumped-parameter model, using a case study from Tajikistan. Hydrogeol. J. 6 (2), 226-232.

Rainey, T.B., 1999. Environmental review: managing the Kuybyshev reservoir in the new Russia: a status report. Environ. Pract. 1 (01), 48-55.

Rauch-Williams, T., Hoppe-Jones, C., Drewes, J.E., 2010. The role of organic matter in the removal of emerging trace organic chemicals during managed aquifer recharge. Water Res. 44 (2), 449-460.
Ray, C., Soong, T.W., Lian, Y.Q., Roadcap, G.S., 2002. Effect of flood-induced chemical load on filtrate quality at bank filtration sites. J. Hydrol. 266 (3-4), 235-258.

Rivière, A., Gonçalvès, J., Jost, A., Font, M., 2014. Experimental and numerical assessment of transient stream-aquifer exchange during disconnection. J. Hydrol. 517, 574-583.

Rosenberry, D.O., 2008. A seepage meter designed for use in flowing water. J. Hydrol. 359 (1-2), 118-130.

Roshan, H., Rau, G.C., Andersen, M.S., Acworth, I.R., 2012. Use of heat as tracer to quantify vertical streambed flow in a two-dimensional flow field. Water Resour. Res. 48 (10), W10508.

Roy, S.B. et al., 2012. Projecting water withdrawal and supply for future decades in the U.S. under climate change scenarios. Environ. Sci. Technol. 46 (5), 2545 2556.

Schilling, O.S. et al., 2014. Using tree ring data as a proxy for transpiration to reduce predictive uncertainty of a model simulating groundwater-surface watervegetation interactions. J. Hydrol. 519 (Part B (0)), 2258-2271.

Schubert, J., 2002. Hydraulic aspects of riverbank filtration-field studies. J. Hydrol. 266 (3-4), 145-161.

Shamsuddin, M., Sulaiman, W., Suratman, S., Zakaria, M., Samuding, K., 2014. Groundwater and surface-water utilisation using a bank infiltration technique in Malaysia. Hydrogeol. J. 22 (3), 543-564.

Shanafield, M., Cook, P.G., 2014. Transmission losses, infiltration and groundwater recharge through ephemeral and intermittent streambeds: a review of applied methods. J. Hydrol. 511, 518-529.

Sheets, R.A., Hill, M.C., Haitjema, H.M., Provost, A.M., Masterson, J.P., 2015. Simulation of water-table aquifers using specified saturated thickness. Groundwater 53 (1), 151-157.

Shestakov, V.M., 1965. Teoreticheskie osnovy ocenki podpora, vodoponijeniya i drenaja [Theoretical base of estimation of an afflux, drawdowns and drainage] (in Russian). Moscow State University, Moscow.

Shestakov, V.M., 1993. Principles, methods and problems of groundwater monitoring (in Russian). Geoekologiya: Inzhenernaya Geologiya Gidrogeologiya, 6: 3-11.

Shestakov, V.M., 1995. Gidrogeodinamika [Hydrogeodynamics] (in Russian). Mosk. Gos. Univ. Moscow.

Shestakov, V., 2002. Development of relationship between specific storage and depth of sandy and clay formations. Environ. Geol. 42 (2-3), 127-129.

Shestakov, V.M., Pozdniakov, S.P., 2003. Geohydrology (in Russian). Academkniga, Moscow.

Shestakov, V.M., Wang, P., 2004. Hydrogeodynamic monitoring at water intake sites on the bank of the Voronezh Reservoir (in Russian). Mosc. Univ. Geol. Bull. 1, 60-64.

Singh, P., Kumar, P., Mehrotra, I., Grischek, T., 2010. Impact of riverbank filtration on treatment of polluted river water. J. Environ. Manage. 91 (5), 1055-1062.

Sprenger, C. et al., 2011. Vulnerability of bank filtration systems to climate change. Sci. Total Environ. 409 (4), 655-663.

Tufenkji, N., Ryan, J.N., Elimelech, M., 2002. The promise of bank filtration-a simple technology may inexpensively clean up poor-quality raw surface water. Environ. Sci. Technol. 36 (21), 422A-428A.

Vogt, T., Schirmer, M., Cirpka, O.A., 2012. Investigating riparian groundwater flow close to a losing river using diurnal temperature oscillations at high vertical resolution. Hydrol. Earth Syst. Sci. 16 (2), 473-487.

Wang, P., 2008. Investigation of the Flow Processes in Riverbank Water Supply Well Fields Near Reservoirs (Ph.D. thesis, in Russian), Lomonosov Moscow State University, pp. 153.

Wang, X.-S., Wan, L., Hu, B., 2009. New approximate solutions of horizontal confined-unconfined flow. J. Hydrol. 376 (3-4), 417-427.

Weiss, W.J. et al., 2005. Riverbank filtration for control of microorganisms: results from field monitoring. Water Res. 39 (10), 1990-2001.

Wiese, B., Nützmann, G., 2009. Transient Leakance and infiltration characteristics during lake bank filtration. Ground Water 47 (1), 57-68.

Wu, Y., Hui, L., Wang, H., Li, Y., Zeng, R., 2007. Effectiveness of riverbank filtration for removal of nitrogen from heavily polluted rivers: a case study of Kuihe River, Xuzhou, Jiangsu. China Environ. Geol. 52 (1), 19-25.

Yong, C.F., McCarthy, D.T., Deletic, A., 2013. Predicting physical clogging of porous and permeable pavements. J. Hydrol. 481, 48-55.

Zhou, Y., 1996. Sampling frequency for monitoring the actual state of groundwater systems. J. Hydrol. 180 (1-4), 301-318.

Zhou, Y., Dong, D., Liu, J., Li, W., 2013. Upgrading a regional groundwater level monitoring network for Beijing Plain, China. Geosci. Front. 4 (1), 127-138.

Zlotnik, V.A., Huang, H., 1999. Effect of shallow penetration and streambed sediments on aquifer response to stream stage fluctuations (analytical model). Ground Water 37 (4), 599-605. 